\title{
Prediscursive Technical Communication in the Early American Iron Industry
}

\author{
Carol Siri Johnson \\ New Jersey Institute of Technology
}

\begin{abstract}
Examing the discourse surrounding the charcoal iron industry between 1760 and 1860 in North America, this article suggests that, prior to the industrialization of work, technical communication took place in a prediscursive setting, an oral and physical world that we can just manage to glimpse even as we watch it recede. The letters of Robert Erskine written in 1770 illustrate the prediscursive methods of technical communication. By the 1860 s, a flood of governmental, professional, and commercial publications appeared, each signifying the disappearance of this prediscursive world. This transition from prediscursive to discursive methods may mark one of the largest changes in the history of technical communication.
\end{abstract}

Technical communication is the language of everyday life. According to Tebeaux (1997), it is about "farming, gardening, animal husbandry, surveying, navigation, military science, accounting, recreation, estate management, household management, cooking, medicine, beekeeping, and silkworm production, to name a few" (p. 3). Although we often equate technical communication with technical writing, many industries grew and spread without using writing; prior to industrialization, technical communication happened in a prediscursive setting by physical and oral means. The early American iron industry offers one example of such a prediscursive setting, having no user manuals, directories, or references; knowledge was transmitted in close physical proximity, orally and by demonstration and imitation. As the industrial age approached, however, printed texts began to emerge, and soon there were state reports, industrial directories, trade journals, and manuals that discussed the common tasks of ironmaking. These early texts were notable for their fluid genre and their rich and detailed illustrations. With the increasing complexity of everyday life, textual and visual methods of communication entered the repertoire of tools for working.

Several bibliographies of the history of technical communication relevant to my study have been published (Brockman, 1983; Moran, 1985; Rivers, 1999). As 
Rivers (1999) noted (quoting Brockman), to understand its history, those in the technical communication field will have to study "a broad spectrum of celebrated and uncelebrated writers" (p. 251). Brockman $(1996,1998)$ published studies of noncanonical authors. Complementing this work, Moran $(2003,2005)$ published articles on precolonial commercial reports, and Yates (1989) and Longo (2000) published studies focused on periods after 1850 . We do not yet, however, have a study of technical communication practices in the 18th and mid-19th centuries. This article fills that gap. I chose to research an industry rather than an individual, and to read as much of its technical communication as I could find. This method allowed me to focus on the evolution of the iron industry's genres and language practices on a broad social scale. By studying an industry, we can see people interacting via social networks; we can see genres emerge and listen to voices not yet heard in our scholarly studies.

First, I discuss the history and processes of ironmaking. I then describe two fragments from the prediscursive world - an 18th-century apologia by a failed ironmaster and a series of letters by Robert Erskine (1770), a Scottish engineerthat can give insight into the prediscursive world of technical communication. The third section of this article describes the emergence of printed texts in the mid-19th century. These texts reflect a relative landslide of publications about the iron industry, which resulted from the shift to industrialization. These sources are only a small selection of the material available, but they illustrate the transformation from prediscursive, oral, and physical methods of technical communication to more formal printed communication (but in which the genres were still fluid).

The preliterate cultures Ong (1982/1988) described can be compared to the prediscursive state of technical communication in the early American iron industry. According to Ong, an oral culture "has nothing corresponding to how-to-do-it manuals for the trades" (p. 43). The ironworkers transferred their knowledge from one to another by "observation and practice with only minimal verbalized explanation" ( $\mathrm{p}$. 43). According to Ferguson (1992), engineering "has depended heavily and continuously on nonverbal learning and nonverbal understanding" (p. xi). Ironmaking knowledge was tacit knowledge, carried within the individual or group; it was physically localized and moved only when ironworkers moved. In the 19th century, this prediscursive, mainly oral culture made the transition to a chirographic one, a culture that used drawings and words. This transition from prediscursive to discursive methods may mark one of the largest changes in the history of technical communication. Neither method, of course, is superior: Knowledge was transmitted more efficiently in prediscursive communication, but more broadly in print.

\section{IRONMAKING PROCESSES}

Charcoal ironmaking was a common industry in America until the 20th century. Forges and furnaces dotted the landscape where waterpower, iron ore, and wood 
for charcoal were plentiful. The first ironworks were mainly small, family-run operations, but by the 18th century large-scale enterprises were beginning to appear, partly to supply the Colonies with iron and partly to take advantage of the high cost of iron in Europe. In Europe, both Germany and Britain employed sophisticated ironmaking techniques but were running low on resources, especially wood for charcoal. German and English workers brought their tacit knowledge to America and, once there, worked together to develop new methods. By 1775, the American Colonies were the world's third largest producers of iron (Gordon 1996, p. 58). During the 19th century, the industry expanded and contracted (always subject to the vicissitudes of supply and demand), and then exploded into the industrial megalith of the 20th century.

Ironmakers needed to understand many complex technological processes as part of their works. They built dams and raceways to power the waterwheels that, in turn, powered the bellows and trip hammers for the forges and furnaces. Blast furnaces were the central part of a complex of buildings used for ironmaking. These furnaces were about 24-feet high with arches in the base and a hole at the top. Workers wheeled the ore, charcoal, and flux across a charging bridge to the top of the furnace and poured them in by the basketful. Air, forced into the furnace through a tuyere pipe, created the high temperatures necessary to melt the ore. If the blast proceeded without failure, the furnace ran for months, and the molten iron was poured periodically into dampened molds of sand, called pigs, on the floor.

Contemporaneous images of these processes in early America do not exist. By mid-19th century, woodcuts and etchings of portions of the ironworks began to appear, but they seldom illustrated the whole. Thus in his pamphlet, Making Iron and Steel: The Historical Processes, 1700-1900, Chard (1995) had to create his own representation for the modern eye (see Figure 1).

\section{The Blast Furnace}

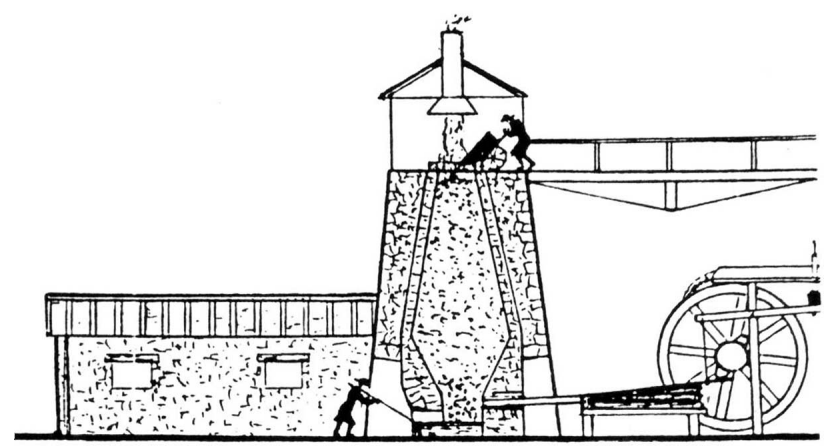

FIGURE 1 Illustration of a charcoal iron blast furnace, circa 1770. From Making Iron \& Steel: The Historical Processes, 1700-1900 (3rd ed.), by J. Chard, 1995, Ringwood, NJ: North Jersey Highlands Historical Society. Reproduced with permission courtesy North Jersey Highlands Historical Society. 
Ironworkers had to be highly skilled. Because each ore was slightly different (from mine to mine and within a mine) and because slight fluctuations in temperature changed the chemical interactions inside the furnace, ironworkers needed to adjust the amounts of ore, flux, and charcoal constantly. As Chard (1995) wrote, even the small hearth process required great skill:

The temperatures had to be judged by eye; and the progress of the reactions had to be determined by the 'feel' (viscosity) of the liquid iron as the operator stirred it and the carbon content changed, with consequent change in melting temperature. (p. 19)

Ironworkers, while doing heavy physical labor, were constantly assessing and adjusting all aspects of the procedure: They needed to have expert knowledge and execute it at all times without error.

Operating the blast furnace was only one part of the ironmaking process, beginning with mining ore, which took place by drilling and blasting with black powder. Later, after the pig iron was made, founders beat it into bar iron (thereby changing the chemical content) or poured it into molds. Charcoal making was also a sophisticated technological process, and colliers made as much money as expert ironworkers (Gordon, 1996, p. 34). The quality of the charcoal depended on the type of tree, when it was cut, and the strength and direction of the wind while it burned. Like ironworkers in the blast furnaces, colliers used physical clues to gauge the state of the process: "They watched the color of the smoke, which they could control by draft holes at the base of the cone" (Gordon, p. 36). Like ironworkers, colliers worked in conditions where one wrong step could result in injury, destruction, or fire.

Whether it was operating a furnace hot enough to melt rock, making charcoal by burning trees in a forest, or using explosives to pry rock from the ground, ironmakers practiced a technologically sophisticated and dangerous art. Nevertheless, the industry grew and flourished for many centuries without the aid of scientific knowledge, written communication, or documented procedures. Ironmakers used modes of communication that enabled them to communicate in adverse conditions with perfect coordination to avoid danger and produce iron. This prediscursive method of communication, as Erskine's (1770) letters show, was physical and oral; ironmakers watched, listened, felt, smelled, and sometimes exchanged words while working in unison.

\section{PREDISCURSIVE TECHNICAL COMMUNICATION}

Both Gordon (1996, p. 313) and Chard (1995, p. 19) noted the absence of books published prior to 1800 that would have been of use to working ironmakers, even if the ironmakers could read. As Yates (1989) explained, before the 19th century "written communication was limited to formal documentation of monetary trans- 
actions and informal correspondence across physical distances" (p. 2). Ironmasters rarely kept any records other than financial ones. One exception is furnace journals, daybooks that recorded the workers' schedules, each day's events, and notes about the furnace. There are also occasional writings that describe the iron industry, including an apologia by the ironmaster Peter Hasenclever (1773/1970) and a series of letters by Erskine (1770), who systematically set out to describe the industry. These and the related but scattered and fragmentary texts that exist are invaluable because they can shed light on the world of prediscursive technical communication.

\section{Hasenclever's Apologia}

Hasenclever (1773/1970) wrote an apologia after the failure of his ironworks in 1773. Moran (2003) defined an apologia as "an ancient genre of rhetoric still practiced today, in which speakers and writers publicly justify their actions and decisions that have been questioned by critics" (p. 127). According to Boyer (1931), Hasenclever raised $£ 40,000$ in England to build a large-scale ironworking operation in America, but within 3 years he had spent $£ 54,000$ (p. 13). Hasenclever's apologia was, in part, a justification of his expenditures. However, he also described the building of the ironworks and shed some light on the state of the early American iron industry. We can use his description to gain insight into the discourse environment of the ironworkers, conditions in the working world, and the way knowledge traveled.

In prediscursive technical communication, knowledge resided within the worker, and when the worker moved, the knowledge also moved. Thus, to start the ironworks in America, Hasenclever hired experienced laborers from Germanyforgemen, furnace men, charcoal burners, miners, masons, carpenters, and others - and in 1764 he transported them, along with their families, to New Jersey. These experienced workers built five ironmaking villages, each with a furnace, multiple forges with multiple fires, stamping mills, coal houses, blacksmith shops, houses, saw mills, reservoirs, ponds, bridges and roads, in an extremely short time, from 1764 to 1767 . However, the German workers soon became dissatisfied with their wages in America. According to Hasenclever (1773/1970)

The refractory disposition of the people was also a troublesome affair; they had been engaged in Germany to be found in provisions; they were not to be satisfied; the Country People put many chimeras in their heads, and made them believe, that they were not obliged to stand to the contract and agreements, made with them in Germany; they pretended to have their wages raised, which I refused. (p. 9)

This passage illustrates that, despite language problems, the recently arrived German ironmakers were able to communicate with the people who were already there 
("the Country People" that Hasenclever referred to in the passage) well enough to know they were overworked and underpaid. After the failure of Hasenclever's ironworks, his workers dispersed to the surrounding towns, taking their knowledge with them. Some worked at other ironworks; others started their own. This was how the ironmaking knowledge traveled in America.

Movement in search of higher wages was characteristic of American ironworkers. According to Gordon (1996), "artisans moved about, worked for different ironmasters, exchanged information with their peers, and displayed their particular skills to interested observers" (p. 2). Moreover, many people learned ironmaking because, "unlike secretive European masters, or artisans in the closed African iron smelters' camps, Americans let neighbors and children stop by their smithies, forges, and furnaces to watch and learn" (p. 2). According to Wearing (2004), women and children also worked in these operations; one task they performed was sorting the waste rock from the ore. Ong (1982/1988) noted that apprenticeships in general took place by "observation and practice with only minimal verbalized explanation" (p. 43), and thus apprentices were able to overcome language barriers. Prediscursive communication enabled the iron industry to spread from town to town and state to state, with the industry's workers transmitting technical knowledge without written documentation.

\section{Erskine's Letters}

Robert Erskine, who was hired to replace Hasenclever, was a conscientious Scottish engineer whose specialty was hydraulics. To overcome his lack of knowledge about ironmaking, he took a tour through Wales, England, and Scotland to visit mines, forges, furnaces, and foundries. Erksine's (1770) detailed letters may have been an afterthought because it was not until the first letter to his employer Richard Atkinson that he stated

I may not omit particulars which hereafter may be useful, I hope you will excuse me, in this and all my future Letters, for giving a detail of my observations, in the same order in which they occurred, by following this rule, tho I may mention some things trivial and of no avail, yet I shall run the less hazard of overlooking things of Importance. (September 15)

The fortuitous result of this decision was 13 letters, ranging from two to six tightly written pages (e.g., see Figure 2) in which he described to the best of his ability the multiple processes involved in mining, smelting, and casting iron.

Erskine (1770) had no trouble getting information from the ironworkers because "a few shillings was a very agreeable present to men who with families of 6 or 7 Children earned only 12'S a Week" (September 16). To facilitate his information gathering, he preferred to speak to the workmen rather than the owners. He wrote of 


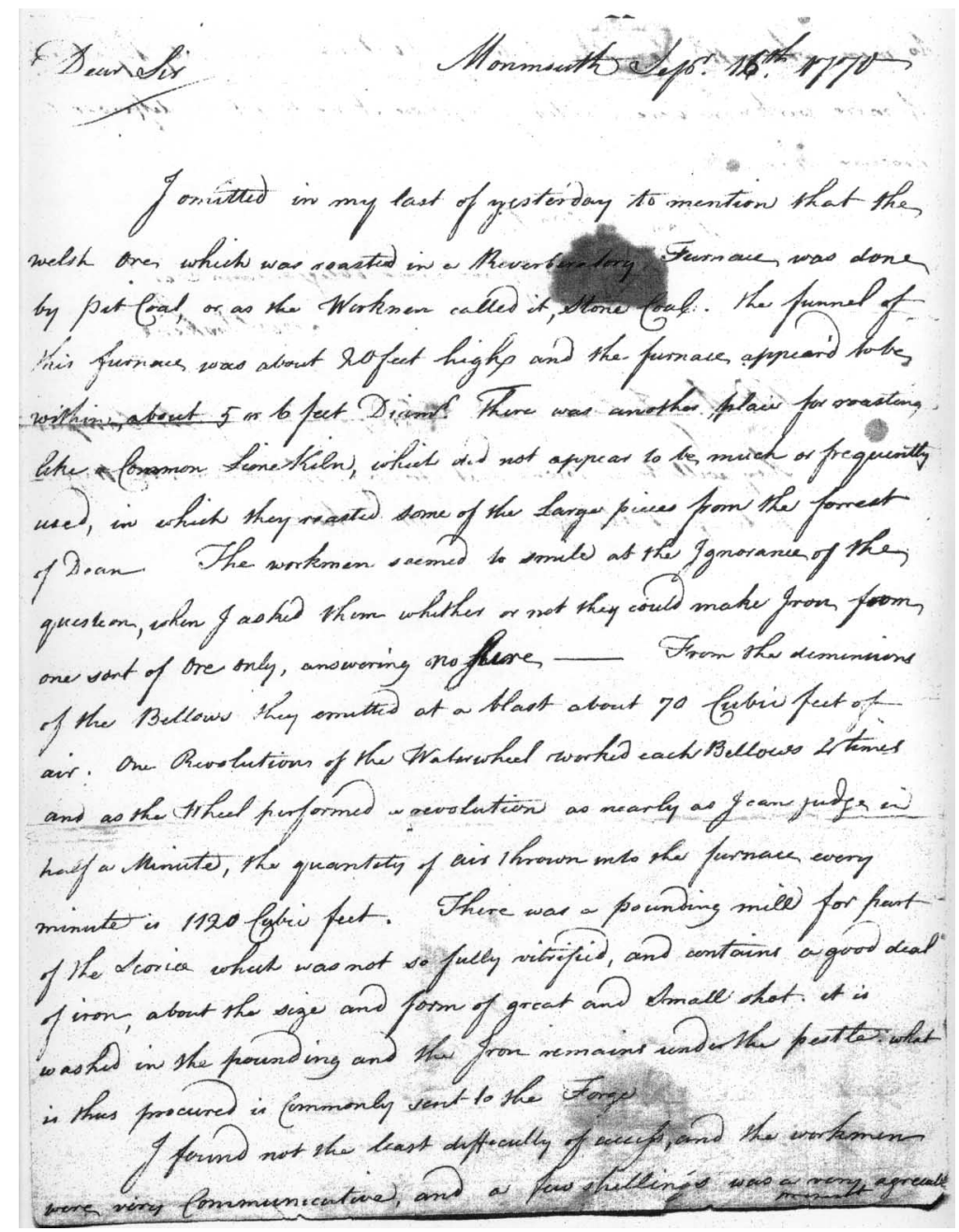

FIGURE 2 Letter from Robert Erskine to Richard Atkinson, September 16, 1770. From The Manors and Forges of Ringwood Compilation, 1759-1923 (vol. 2, p. 4), Trenton: New Jersey State Archives. Reproduced with permission courtesy New Jersey State Archives.

one owner who "had he accompanied me through the works, my view must have been more Cursory and superficial, nor could I in his hearing, have taken the liberty to ask such questions at the workmen, as I did when by myself" (November 10).

Erskine's (1770) early letters are largely an account of remembered conversations-his questions and the workmen's answers-and descriptions of physical activities. His sentences often start with "one of the men told me" or "I saw them." 
He recorded everything in as much detail as possible. Some of his descriptions are so clear that it is easy for the reader to visualize the ironworker's actions:

They push the pig which was melting, out of the Blast, and keep stirring the metal til it unites in one mass, about the size and shape of a Round half peck loaf. It is then lifted by mere strength of hand, under the hammer, by one of the forge men, the other in the mean time regulating the stroke, which is at first slow and then gradually increases to about two beats a second. (September 21)

In the ironmaking process, empirical skill was essential. Often workers judged the stage of the process by color, smell, or feel. They judged the quality of the ore by its color as it lay rusting: "That which turned rusty soonest, they looked on as the best" (Erskine, 1770, September 27). They knew when to open a slag hole by its feel: "The dross itself in Cooling stops the hole; and they know when to open it, by practice, and what sticks to the end of the poker" (Erskine, September 19). This is the sort of knowledge that can be transferred only in close physical contact.

During the 18th and most of the 19th centuries, no one understood the chemical processes that went into making charcoal iron. The laborers found, through trial and error, which combinations produced the best iron from each ore. It was not until the late 19th century that scientists finally understood the chemical processes that went into making iron, and until then, printed texts relayed myths, such as the myth that some ores were better than others. According to Gordon (1996), "Americans often believed that possession of particular ores or fuels would make them wealthy" (p. 27). The ironworkers themselves knew, as Erskine (1770) noted, that this was not true and that "any sort of Iron may be made from any kind of Ore" (September 29). Erskine earlier wrote, "The workmen seemed to smile at the Ignorance of the question, when I asked them whether or not they could make Iron from one sort of Ore only, answering no Sire" (September 16).

Another common misunderstanding that carried over into the 19th century and its texts was the causes for the brittleness and malleability of iron. Early 19th century texts, according to Gordon (1996), "repeated the old theory that disparities in grades of iron were due to differences in oxygen content" and that this oxygen content affected the malleability of the resultant iron (p. 313). Here again, however, the oral knowledge outstripped the written knowledge; when Erskine (1770) asked a workman what controlled the malleability, the answer that he received was that "a great deal of the quality of the Iron depended upon the proper quantity of Charcoal, be the Ore what would" (September 27).

In Erskine's (1770) later letters, he spent less time describing the interactions between the ironworkers and more time describing the machinery. In Birmingham, he saw machinery that sent him into raptures of delight:

At Mr Boltons Works Mechanics are in perfection, both in perfection, both, in animate and alive, but I must give the preference to the Machinery, some engines being 
so constructed that a man or a boy will execute the work equally well, and in many cases, a blind man could do as well as either. (October 11)

Even during Erskine's time, technology was changing, moving to a more complex industrial (and impersonalized) world. From this point on in the letters, his words "they" and "the Workmen" ceased, and instead Erskine devoted many pages of closely written text to describing machines. The shift in Erskine's letters presaged the shift from prediscursive modes of technical communication to the more distanced and theoretical world of documentation that followed.

\section{THE EMERGENCE OF PRINTED DOCUMENTATION}

In part, it was the increasing mobility of the ironmasters that started the avalanche of printed documentation in the middle of the 19th century; railroads and improved transportation allowed them to get together to discuss the industry, form trade groups and industrial associations, and convince state legislatures to fund geological surveys. At the same time, industrial publishers found that there was a healthy market for books about practical topics including ironmaking. The publications described in the following paragraphs mark the beginning of the comparative flood of printed documentation, a watershed from the prediscursive form of technology transfer to the complex system that we use today.

Increased documentation both enabled industrialization and was enabled by it. As Yates (1989) observed, creating written documentation was necessary "to rise above the individual memory and to establish an organizational memory tied to job positions and functions, rather than to specific individuals" (p. 6). However, this goal can be seen only in retrospect. In the first documents published by and about the iron industry, one can still hear individual voices and each act of writing responded to a specific situation, rather than a preexisting genre. Miller (1984) defined "genres as typified rhetorical actions based in recurrent situations" (p. 159). In the 1850 s, the rhetorical actions in the ironmaking industry were not yet typified; the genres were just beginning to emerge. The efforts to publish were financed only intermittently by different groups. The material in the various genres overlapped, and the ownership of that material had to be negotiated. Despite all of this, the 19th century saw the emergence and evolution of industrial literature.

To explore these emerging genres, I discuss two state reports, an industrial directory, and two commercial manuals. Although the genres are different, they have one thing in common: Each begins with a report or preface that states the purpose of the publication, the contributors to the publication, and history (if any existed). Often they also apologize in advance for any shortcomings. These introductory statements are surprisingly passionate at times. Devitt, Bawarshi, and Reiff (2003) argued that "genre study allows students and researchers to recognize how "lived textuality' plays a role in the lived experience of a group" (p. 542). These docu- 
ments show how, in the 19th century, people began to live, communicate, and express themselves through textaulity. Moreover, lived textuality had become a forum for gathering knowledge and power.

\section{State Reports}

State reports were the first publications to be potentially useful to ironmakers. According to Gordon (1996), "as educated individuals turned their attention to the application of science to economic development in the early 19th century, some of them convinced their state legislatures to appropriate money for geological surveys intended to find economically useful mineral resources" (p. 31). States hired state geologists who then hired researchers to do seasonal work in the field. At the end of a survey period, the state geologist assembled the report with illustrations prepared by engravers. Some of the reports were attractive publications with hundreds of detailed drawings illustrating the machinery being used, the layout of the mines, the geographical strata, and the miners at work. However, because they never generated a visible financial return, their funding was often pulled; some projects were cancelled, and others were printed on substandard paper. Nevertheless, they were the first real contribution to printed ironmaking knowledge in America. Like ironmaking itself, collecting this information was a group effort; the state surveyors, many of whom were initially untrained, walked the forests and visited the mines to collect knowledge about the geological strata in each state. The main impetus for financing state geological reports was to strengthen the mineral industries, but the state surveyor also collected knowledge about prospecting, extracting ore, hauling, hoisting, drainage, and ventilation.

Because the state report was a genre just beginning to form, the state geologists who authored the final reports included detailed prefaces that explained their procedures, the dates of investigation, successes and failures, and the names and activities of all participants. For instance, in the Second Annual Report on the Geological Survey, of the State of New Jersey, for the Year 1855, Kitchell (1856), state geologist, began his 250-page report with a 50-page explanation titled "Report on the Organization of the Survey and Finances," which itself is split into two subsections: "Topographical Department" and "Report on the Topographical Department." The difference between these two subsections is unclear and will remain so because abruptly, after page 16, the geology report is replaced, in medias res, by a report from the superintendent of the city schools regarding establishing equitable schools in "the great work of Universal Education" (pp. 17-31). The publisher of the report, The True American Office, was a precursor to state and governmental printing offices of today. The content of the existing front material, however, shows that the work behind the report was as important as the report itself and that the names of all contributors and researchers were included, each mapped to their 
individual contributions. The state's ambivalence about the report is evident in the low grade of paper upon which it was printed: It is extremely brittle, and thus very few copies can be found today.

Another commonality in the evolving discourse surrounding the iron industry was the use of drawings to communicate physical realities. Kitchell (1856) described how his engravings were created "from transfers made upon wood, directly from the rough sketches, and by the same artist who took them in the field" (p. 15). The illustrations, an example of which is shown in Figure 3, were very detailed with lettering mapped to descriptions in the text. Because photography was not fully developed at this time, drawings such as this are the only technical specifications for machinery in the charcoal iron industry that exist today. The actual technology transfer was still accomplished with prediscursive technical communication-one worker teaching the next. Nevertheless, echoing Yates' observation that documentation was necessary "to rise above the individual memory," the act of documenting this industry was the first step toward creating an organizational memory that could span distances. In the case of the charcoal iron industry, the transfer from prediscursive to discursive knowledge did not happen in time and the art of charcoal ironmaking is now a lost art (Chard, 1995, p. 19).

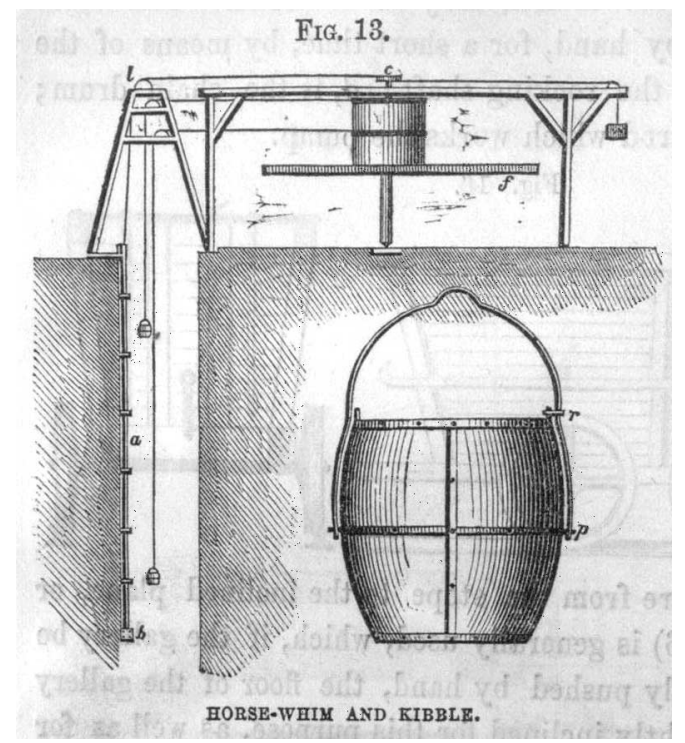

FIGURE 3 Illustration of a horse-whim and kibble. A whim is a drum turned by horse power to raise ore in a kibble, or iron bucket. From Second Annual Report on the Geological Survey, of the State of New Jersey, for the Year 1855 (Rpt. 1856), by W. Kitchell, 1856, Trenton, NJ: The True American Office. 


\section{American Iron Association}

The American Iron Association, one of the industrial groups that encouraged the state reports (and frequently contributed researchers), held its first national meeting in 1849. It was at this time that the ironmasters decided to collect and publish statistics (Baer, 1998). In 1859, J. Peter Lesley, the secretary of the organization, published the gathered information in The Iron Manufacturer's Guide to the Furnaces, Forges and Rolling Mills of the United States with Discussions of Iron as a Chemical Element, an American Ore, and a Manufactured Article, in Commerce and in History. Lesley's goals, as stated in his preface, were broad:

Firstly, of a Guide or Directory to all the Iron Works of the Union and Canada; and Secondly, of Discussions of Iron as a chemical element, as an ore, as a manufactured article and as an object of commerce and history. (p. vii)

His preface also described the history and the making of a nearly 800-page book. Although he declared that "condensation has been attempted everywhere even at the expense of style" (p. viii), the preface belabors the point:

\footnotetext{
It has never been forgotten for a moment that a useful book of this kind can have no personality, and that all writing for writing sake is an impertinence. If any parts are found to be obscure, the Secretary trusts that this may be accepted as to some extent his valid excuse. He has not indeed aimed at making the book a mere bin of dry fact dust; for the conclusions of experience are worth more than all undigested facts. $\mathrm{He}$ has not shrunk from personal statements and extended discussions where the scientific practical interest of the topic seemed to him to call for such. But neither has he indulged in verbose episodical speculations, however tempting the opportunity, nor quoted the more eloquent passages of authors to adorn the theme. The object of the book is use, not recreation. (p. viii)
}

Condensation may have been the goal of the directory, but it was not achieved. Methods for compiling such a book were unclear because it had never been done before. In Lesley's preface, one can see his thought process at work as he approached the problem: He strove for practicality and voiceless objectivity, but he immediately contradicted himself.

The Iron Manufacturer's Guide was separated into two main sections: a lengthy listing of all the ironworks, both existing and idle, in North America and a discussion of ores and chemical interactions. The result was a useful, if somewhat scattered, miscellany. Ong (1982/1988) noted that in literate cultures the past becomes "an itemized terrain, peppered with verifiable and disputed 'facts' or bits of information" (p. 97). Lesley (1859) was collecting these facts here, and he used visual clues to organize the information. There were a detailed table of contents and two separate indexes. According to Ong, "the alphabetic index is actually a crossroads 
between auditory and visualist cultures" (p. 123), and Lesley was using many oral clues to point to visual information. Lesley also included a section on ironmaking technology that he carefully arranged with headings and subheadings; here he was using space and layout to guide the eye. The lists of ironworks used different font sizes, depending on whether the ironworks was active or abandoned.

Lesley's (1859) directory represents the point at which the American iron industry became real to the modern, print-centered world. By listing the ironworks in a publication, Lesley took the ironworks out of the fluid exchange of remembered discourse and fixed them in the print culture. Spoken knowledge, even though it is accurate and powerful, can quickly be forgotten. Written knowledge makes an attempt to be permanent and to communicate in a common language to distant readers. Prior to Lesley's publication, no listing of ironworks in America existed. After his publication, each ironworks was a part of a larger, identifiable social context.

\section{Overlapping and Negotiation of Genres}

Although these genres were evolving, they were influenced by unspoken rules. When Rogers (1858), state geologist for Pennsylvania, published his final state report, he broke one of these rules. His massive publication, The Geology of Pennsylvania, represented the work of many researchers over many years, but unlike the works of both Kitchell (1856) and Lesley (1859), his preface was only eight pages long, and it mentioned only some of their names. The two beautifully printed volumes were published in 1858, one year before the Iron Manufacturer's Guide. Thus Lesley (1859) had time to include a response in his preface to his Guide. Although Lesley never mentioned Roger's name or the title of his book, he wrote passionately about "the most brilliant imposture and the most extensive scientific theft of the present age" (p. ix):

In this immense work of nearly 2,000 pages, magnificently illustrated with maps, sections, and pictures of all kinds to the number of nearly a thousand, are the results of the toil of many men for many years, all appropriated by one man to himself,-a man who, apparently upon principle, gives credit to no one else, but practically asserts and compels the world to say, by the way he publishes this book, that he has done it all, has thought it all, and owns it all. (pp. ix-x)

Like the ironmaking genres, the concept of intellectual property was in flux. It was still expected, at this time, that the compilers of multiple-authored documents include a detailed description of each author and their contribution. Although eventually technical communication evolved more toward Rogers's model, at the time Lesley's method prevailed. Lesley (1876) became the state geologist of Pennsylvania and published a post-mortem, Historical Sketch of Geological Explorations in Pennsylvania and Other States, in which he stated that Rogers's report resulted in 
"the annihilation of all historic individuality of the old work and the old workers" (p. 120). The movement from individual voice to objective voice and from individuality to anonymity in technical communication was not a straight line-it was a recursive process that allowed multiple forms of a genre to coexist until common elements emerged and became the norm.

Rogers's (1858) report was as luxurious as Lesley's (1859) directory was plain. He included more than a thousand "Views and Sections," 50 full-page "Sketches of Scenery," and many foldout pages for geological sections of rivers, ore beds, and the like. The researchers were inclusive; like Erskine (1770), they did not know what to look for so they recorded everything. Figure 4 shows one example: It is one page of a four-page foldout drawing illustrating nearly every feature along the banks of the Schuylkill River. The illustrations that Rogers included in The Geology of Pennsylvania, gathered from 15 years of research and drawing in the field, demonstrate the closeness of art to technology in the preindustrial world. They support Ong's (1982/1988) theory that "the shift from oral to written speech is essentially a shift from sound to visual space" (p. 115). As Lesley (1876) wrote, these drawings were "fit for the walls of any museum in the world" (p. 133). For the modern viewer, they are as close as we can get to seeing the physical realities of the iron industry prior to the late 19th century.

\section{Practical Manuals}

In the 1850s, Henry Carey Baird \& Co., Industrial Publishers, started publishing the first series of technical and industrial manuals in America. From this point until his death in the early 20th century, Baird and his firm published hundreds of manuals, such as The Paper-Hanger's Companion, Sheep Husbandry in the South, and Miss Leslie's Complete Cookery. Unlike the state reports and industrial directories, these manuals were written for profit. Tebeaux (1997) noted about the Renaissance that "printers soon saw that a market existed for instructional books that covered a variety of practical subjects" (p. 10), and similarly, Baird saw a reading public emerge in 19th century America that would pay for knowledge. In other aspects, however, the practical manuals were similar to the other genres - the state reports and industrial directories - in that they, too, began with a preface in which the author tried to state his goal, and they, too, relied on visual illustrations for knowledge transfer.

The first commercial manual about the iron industry in America was Overman's (1854) The Manufacture of Iron, in All Its Various Branches, first published in 1850. In his preface, Overman immediately stated, "This book has been written with a special regard to practical utility" (p. iii), but just as immediately, he began to equivocate, as if in response to his own statement: 


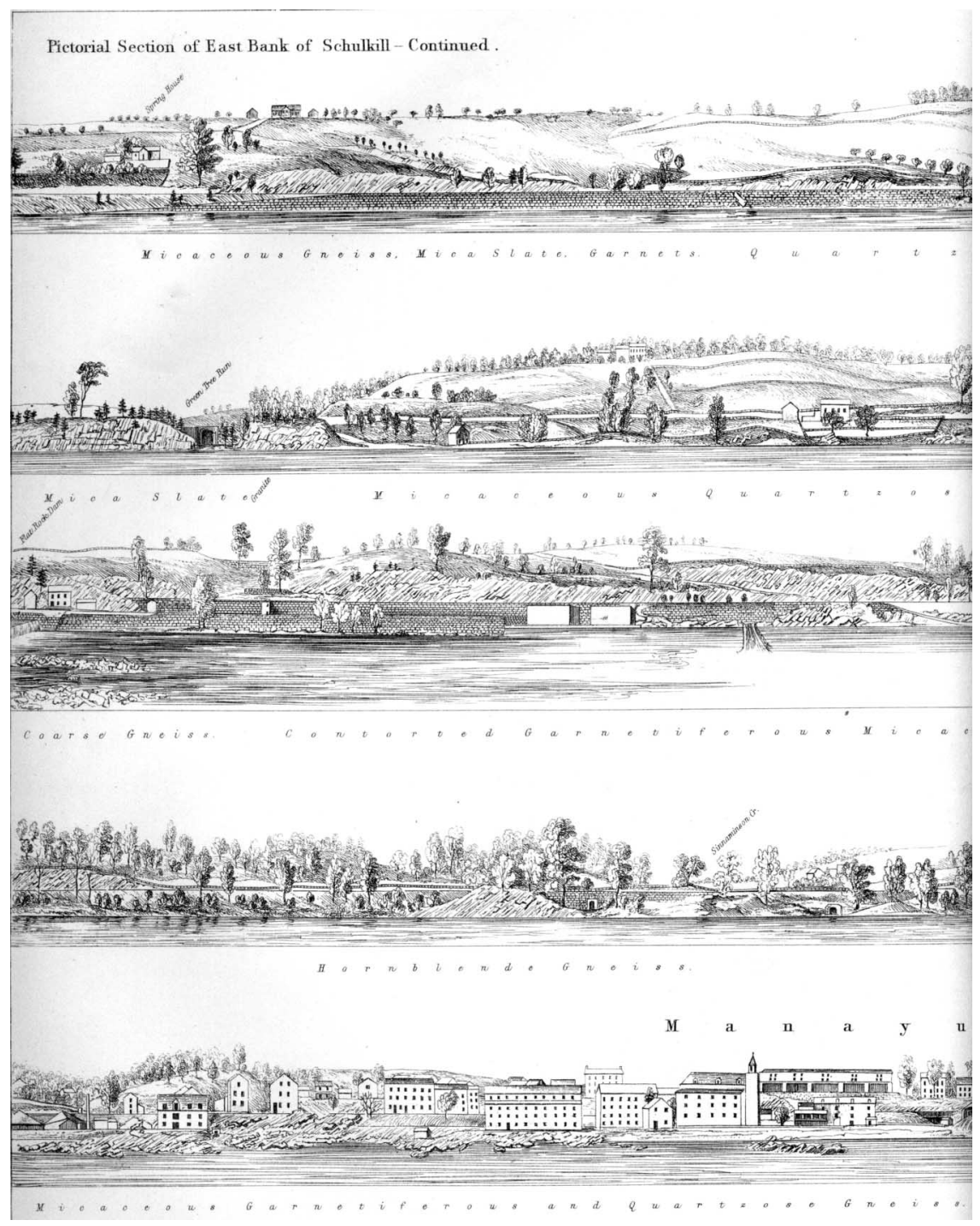

FIGURE 4 One page from a four-page foldout showing the detail of observation by geological surveyors in the 19th century. This foldout was only one of several that illustrated features of the Schuylkill River. Illustrations such as this were drawn by the surveyors in the field. From The Geology of Pennsylvania (vol. 1, pp. 46-47), by H. D. Rogers, 1858, London: W. Blackwood and Sons. 
A mere description of materials and of manipulations amounts to nothing more than an enumeration and record of facts. This we considered insufficient to satisfy the wants of an inquisitive community. Therefore, each division of the book contains a philosophical investigation concerning the apparatus and manipulations applicable to specific cases, as well as the basis whence their relative advantages are deduced. (p. iii)

Although Overman (1854) intended to be practical, like Lesley (1859), he found practicality hard to achieve. As Gordon (1996) noted, "[He] spread contradictory assertions liberally through his text" (p. 317). Overman (1854) illustrates the shifting sands of industrial and scientific discourse during this time: In his case, he aspired to create scientific theory and died from poisoning while engaged in chemical analysis (Overman, 1852, p. ii). Nevertheless, the book was very popular, and it went through many editions. It met a public demand for general knowledge; it was attractive and instructive, if not entirely accurate.

Like Rogers's (1858) and Lesley's (1859) reports, The Manufacture of Iron was richly illustrated. The title page proudly stated that it is a book "With One Hundred and Fifty Wood Engravings." In the last paragraph of his preface, Overman (1854) wrote, "The publisher has spared no expense in relation to the typography and engravings of this work, which have been executed in a manner equal to anything the country can afford" (p. iv). Figure 5 shows an example of a woodcut from this book that makes technology immediately accessible to nonexperts.

It is probable that Baird instructed the authors to be as practical as possible, to avoid theory, and to include illustrations. A book much later in the series, A Practical Treatise on Foundry Irons by Kirk (1911), echoed Overman's (1854) goals. In his preface, Kirk wrote:

It has been the aim of the author to present, in a condensed form, only such matter as is of practical value to the founder ... and to eliminate as far as possible all theories that have not been established as principles and all laboratory experimental work that has not been fully demonstrated to be useful in actual foundry practice. (p. v)

Like Overman, Kirk stated that his goal was practicality; unlike Overman, he also stated that he would not include theories (philosophical investigations) that did not have practical application. This goal was probably suggested by Baird, eluded by Overman, and finally realized in Kirk. Baird probably also intended every publication to have illustrations; the title page of Foundry Irons declares that it is illustrated (even though there are no illustrations).

The Baird series of practical manuals deserves more attention. In the context of this study, it is one more emerging genre, one more method of how ironmakers attempted to reify and communicate their knowledge. Independent of the state re- 
Fig. 95 .

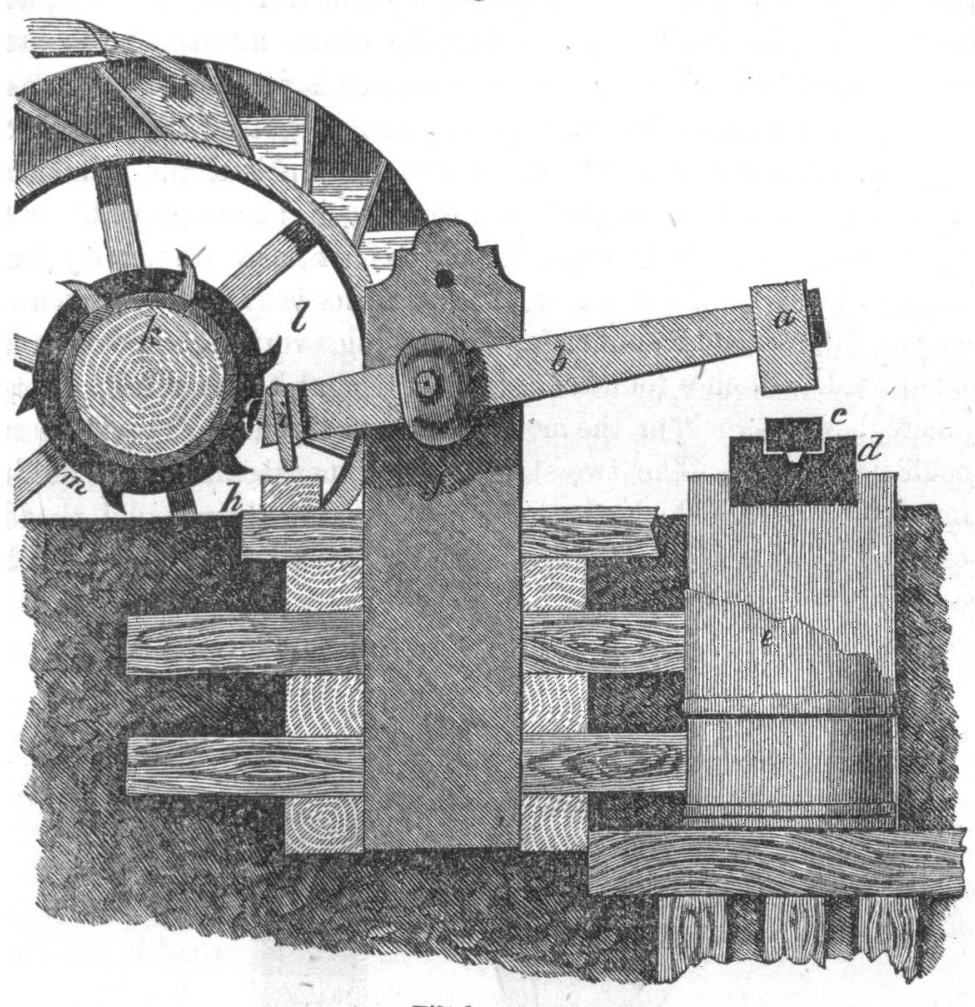

Tilt-hammer.

FIGURE 5 An example of a technical drawing from a commercial manual. This is an illustration and description of a forge tilt hammer, which was a waterwheel-powered device that pounded iron to its desired consistency. From The Manufacture of Iron, in All Its Various Branches (3rd ed.), by F. Overman, 1854, Philadelphia: Henry C. Baird.

ports and industrial directories, it shows that there was a public who was hungry for knowledge. The documentation of the iron industry emerged in the 19th century because it could - there was paper, presses, money, and time- - but also because people wanted to learn more about the world around them.

\section{CONCLUSION}

These publications mark the beginning of a comparative flood of treatises, manuals, surveys, directories, histories, and trade journals about charcoal ironmaking. 
An analysis of what we have long supposed to be detritus (inaccurate books, crumbling state reports, incidental pamphlets, and dull directories) can turn into a multifaceted lens with which we can see how the human world lives and changes. As Miller (1984) observed, "For the critic, genres can serve both as an index to cultural patterns and as tools for exploring" (p. 165). The existing documents (and absences of documents) tell of a transition, or watershed, from a prediscursive, oral form of technology transfer to the verbal and visual complexity inherent in the modern age. We can see the transition that Ong (1982/1988) described, from oral and physical methods of communication to an abstracted, visual and written system of printed communication that could travel distances and serve as a collective memory.

Tebeaux (1997), in her groundbreaking historical analyses of Renaissance texts, argued that "technical writing, like literature, history, and philosophy, is worthy of study in its own right" (p. 2). Technical writing is not just documentation of how people do things; it is also the documentation of how people do things together. In fact, it is a documentation of how the human world (literally) works. By looking closely at these writings that we do not call literature and by studying the genres of the working world, we can hear voices we have not yet heard. The study of technical communication is a vast and rich vein of ore. To extend the metaphor, it is a vein with many types of ore, no one of which is better than any other. The documents that I have discussed here are only a few from a vast expanse of forgotten writing, in which we can find social discourse, the evolution of ideas, art, and fine writing.

\section{REFERENCES}

Baer, C. T. (1998). Guide to American iron and steel records. Retrieved August 25, 2005, from http://www.hagley.lib.de.us/1631.htm

Boyer, C. S. (1931). Early forges \& furnaces in New Jersey. Philadelphia: University of Pennsylvania Press.

Brockman, R. J. (1983). Bibliography of articles on the history of technical communication. Journal of Technical Writing and Communication, 18, 297-304.

Brockman, R. J. (1996). William Stillman, Rhode Island mechanician and communicator-his lock patents and acrostics. Journal of Technical Writing and Communication, 26, 21-35.

Brockman, R. J. (1998). From millwrights to shipwrights to the twenty-first century: Explorations in a history of technical communication in the United States. Cresskill, NJ: Hampton.

Chard, J. (1995). Making iron \& steel: The historical processes, 1700-1900 (3rd ed.). Ringwood, NJ: North Jersey Highlands Historical Society.

Devitt, A. J., Bawarshi, A., \& Reiff, M. (2003). Materiality and genre in the study of discourse communities. College English, 65, 541-558.

Erskine, R. (1770). Letters to R. Atkinson. New Jersey State Archives, Trenton.

Ferguson, .E. S. (1999). Engineering and the mind's eye (5th ed.). Cambridge, MA: MIT Press.

Gordon, R. B. (1996). American iron, 1607-1900. Baltimore: Johns Hopkins University Press. 
Hasenclever, P. (1970). The remarkable case of Peter Hasenclever, merchant. 1773. Ringwood, NJ: North Jersey Highlands Historical Society. (Original work published 1773)

Kitchell, W. (1856). Second annual report on the geological survey, of the state of New Jersey, for the year 1855. Trenton, NJ: Office of the "True American."

Kirk, E. (1911). A practical treatise on foundry irons. Philadelphia: Henry Carey Baird \& Co.

Lesley, J. P. (1859). The iron manufacturer's guide to the furnaces, forges and rolling mills of the United States with discussions of iron as a chemical element, an American ore, and a manufactured article, in commerce and in history. New York: Wiley.

Lesley, J. P. (1876). Historical sketch of geological explorations in Pennsylvania and other states. Harrisburg, PA: Board of Commissioners for the Second Geological Survey.

Longo, B. (2000). Spurious coin: A history of science, management and technical writing. Albany: State University of New York Press.

Miller, C. R. (1984). Genre as social action. Quarterly Journal of Speech, 70, 151-167.

Moran, M. G. (1985). The history of technical and scientific writing. In M. G. Moran \& D. Journet (Eds.), Research in technical communication: A bibliographic sourcebook (pp. 25-38). Westport, CT: Greenwood.

Moran, M. G. (2003). Ralph Lane's 1586 Discourse on the first colony: The renaissance commercial report as apologia. Technical Communication Quarterly, 12, 125-154.

Moran, M. G. (2005). Figures of speech as persuasive strategies in early commercial communication: The use of dominant figures in the Raleigh reports about Virginia in the 1580s. Technical Communication Quarterly, 14, 183-196.

Ong, W. J. (1988). Orality and literacy: The technologizing of the word. New York: Routledge. (Original work published 1982)

Overman, F. (1852). A treatise on metallurgy. New York: D. Appleton \& Company.

Overman, F. (1854). The manufacture of iron, in all its various branches (3rd ed.). Philadelphia: Henry C. Baird.

Rivers, W. E. (1999). Studies in the history of business and technical writing: A bibliographical essay. In T. Kynell \& M. G. Moran (Eds.), Three keys to the past: The history of technical communication. Norwood, NJ: Ablex.

Rogers, H. D. (1858). The geology of Pennsylvania. Philadelphia: Lippincott.

Tebeaux, E. (1997). The emergence of a tradition: Technical writing in the English Renaissance, 1475-1640. Amityville, NY: Baywood.

Wearing, J. (2004, September). Forging the future: Morris County's iron industry. Lecture presented at the Mount Hope Historical Conservancy, Morristown National Historical Park, Morristown, NJ.

Yates, J. (1993). Control through communication: The rise of system in American management. Baltimore: Johns Hopkins University Press.

Carol Siri Johnson received her bachelor of arts degree from Mount Holyoke College and her doctorate from The City University of New York Graduate Center. She worked as a technical writer for 6 years. She is an assistant professor of technical communication at the New Jersey Institute of Technology. 